ECONOMICS, 1945-1955

\author{
BY SERGE BENEST*
}

\begin{abstract}
Following World War II, the director of the Social Sciences Division at the Rockefeller Foundation, the industrial economist Joseph H. Willits, thought it important to extend its activities to Europe, especially France. His agenda was to strengthen institutional economics and to create modern research centers with a view to stabilizing the political situation. In the postwar decade, almost all economic research centers in France were funded by the Foundation, which helped provide greater autonomy to French economists within academia, but failed to reshape French economic training and research.
\end{abstract}

* Universitat de Barcelona, Department of Economic History, Institutions and Policy and World Economy, Spain. Contact: serge.benest@gmail.com.

This "preprint" is the peer-reviewed and accepted typescript of an article that is forthcoming in revised form, after minor editorial changes, in the Journal of the History of Economic Thought (ISSN: 1053-8372), issue TBA. Copyright to the journal's articles is held by the History of Economics Society (HES), whose exclusive licensee and publisher for the journal is Cambridge University Press. (https://www.cambridge.org/core/journals/journal-of-the-history-of-economic-thought) This preprint may be used only for private research and study and is not to be distributed further.

The preprint may be cited as follows:

Benest, Serge. The Politics of Funding: The Rockfeller Foundation and French Economics, 1945-1955. Journal of the History of Economic Thought (forthcoming). Preprint at SocArXiv, osf.io/preprints/socarxiv 


\section{THE POLITICS OF FUNDING: THE ROCKEFELLER FOUNDATION AND FRENCH ECONOMICS, 1945-1955 ${ }^{1}$}

\section{INTRODUCTION}

The role of the Rockefeller Foundation in the postwar French social sciences is wellknown. Some historians of the social sciences note its institutional achievements (Gemelli 1995; Mazon 1988; Tournès 2013) while others put forward its intellectually ambitious agenda for area studies (Popa 2015, 2016, 2017) and for economic history (De Rouvray 2005). By contrast, the impact of the foundation on French economics has received little attention. Historians of economics are only now beginning to look at the role of U.S. foundations in France, with most studies to date dealing with institution-building (for instance Etner and Silvant 2017, p. 420-421; or Tournès 2013, pp. 293-316). Yet, a close examination of the institutional and intellectual dimensions of the Rockefeller's interventions in postwar France shows that its economists were not as isolated as is often suggested.

It is commonplace to emphasize the postwar isolation of French economics and its late internationalization (Le Merrer 2012, p. 164; see also Bourguignon and Guesnerie 1996, p. 337). A number of reasons are advanced to explain why French economics did not take the postwar American turn from interwar pluralism to postwar neoclassicism, as described by Morgan and Rutherford (1998). There was a strong "sociological" tradition in French economics (Fourcade 2009, pp. 195-199); some economists from the faculties rejected mathematics - mainly out of ignorance of formal methods - (Fourcade 2009, pp. 192-193; Etner and Silvant 2017, pp. 414-415); the language barrier was significant (Etner and Silvant 2017, p. 413); there existed an Anglophobic sentiment (Arena 2000, p. 999); and finally the American methodological approach was regarded with skepticism (see, for instance, Allais [1953]).

\footnotetext{
1 For their useful comments and suggestions, I thank Philippe Fontaine, Alain Marciano, Roger Backhouse, Paul Dudenhefer, as well as two anonymous referees of the Journal of the History of Economic Thought and its editor, Pedro Duarte. A first version of this article was presented at the 46th Annual Meetings of the History of Economics Society (Columbia University, 2019). I am grateful to the Rockefeller Archives Center (Tarrytown, NY) and its staff, notably Tom Rosembaum, Mary Ann Quinn, Patricia Rosenfield and James Allen Smith; as well as Yann Potin of the Archives nationales, France. All errors and omissions remain my responsibility.
} 
The above reasons take as their starting point the fact that French economics was isolated. The purpose of this article is to challenge this interpretation. In order to do so, we assess the intellectual and institutional achievements of the Rockefeller Foundation in French economics after WW II. The policy of the Rockefeller Foundation was centered on local initiatives. Thus, in order to appreciate the impact of the political and scientific agenda of the Foundation, it is necessary to study its entire program in France; anything less would, misleadingly, make its actions seem as a piecemeal support, without an overarching purpose. To grasp the originality and impact of the Rockefeller agenda, it is necessary first to study the motivation of the director of its Social Sciences Division, Joseph H. Willits, who supported an institutionalist approach to economics and believed that economic knowledge can help political stabilization. After the liberation, the Rockefeller Foundation oriented its action to Europe, notably the French educational system, because France was perceived as a battleground in the conflict between Communism and liberal democracy. Yet, the officers of the Foundation had to face the rigidities of the French academy (Part 1). As they became acquainted with the institutional constraints of French economics, notably its fragmentation into rival schools of thought, the Rockefeller's officers decided to support a particular kind of French economics known as realistic economics, which they took as comparable to US institutionalist economics (Part 2). Its mission defined, the Rockefeller Foundation tried to implement its program while remaining distant from the inevitable political contingencies of state-governed higher education. Although the ambitions of the Rockefeller's programs were always frustrated by the French government's stranglehold on higher education, the Foundation helped promote French empirical economics (Part 3).

\section{GETTING A FEEL OF FRENCH HIGHER EDUCATION}

"The task of reconstruction after World War II dwarfs any other in history," wrote Joseph H. Willits, the director of the Rockefeller Foundation's division of social science, in 1945. "It is not just a matter of rebuilding what war has destroyed; it is the urgency for creating, for building something different and better that challenges us." 2 That "something different and better" was a social order based on democracy and markets.

\footnotetext{
${ }^{2}$ Report of the work of the social sciences, Rockefeller Foundation Annual report-1945, p.185, Rockefeller Foundation Archives (RFA)-Rockefeller Archives Center (RAC).
} 
This agenda took shape when the Rockefeller Foundation converted the former Laura Spelman Rockefeller Memorial into its social sciences division in 1929. ${ }^{3}$ Aware of the opportunities offered by the new division, the director of the Rockefeller Foundation, Raymond B. Fosdick, urged the newly appointed director of the division, the American educator and economist Edmund Day, to focus on "more concrete policy application related to the current emergency" (Rutherford 2011, p. 117). Consequently, the division concentrated its actions on economics because "the most urgent problems now revolved largely around economic matters" (Seim 2007, p. 288). The idea was to facilitate the production of economic knowledge by promoting a new academic model — the full-time system — to ensure that economists dedicate all of their time to research. ${ }^{4}$ Originally endorsed by the Rockefeller Foundation's division of medical education (Bulmer and Bulmer 1981, pp. 390, 395), the fulltime system was based on the German model, which allowed doctors to fully devote their time to medical research (Tournès 2013, p. 49). In addition, the Foundation promoted the creation of economic research centers where the work of full-time economists was supported by a staff. It deployed this model in the United States, notably at the National Bureau of Economic Research (NBER), and in Europe, for instance at the London School of Economics (Scot 2011, pp. 107-110). In France, the division reorganized the Centre de documentation sociale, created in 1920, and launched the Institut scientifique de recherches économiques et sociales (ISRES), led by the economist Charles Rist (Mazon 1988; Tournès 2006, 2008, 2013).

When Willits replaced Day as head of the division, in 1939, he had to put the program of the social sciences division on hold, refocusing on the exile of European researchers (on exiled French scientists, see Jeanpierre [2004] and Loyer [2005]). Yet, the social sciences division pursued its agenda and economics remained the focus of Willits' efforts during the fifteen years of his tenure (Stapleton 2003, p. 104).

Willits was sympathetic to the institutionalist movement. In his own doctoral research on unemployment in Philadelphia, he had adopted an empirical approach and created his own database, calculating the average distance between employers and unemployment offices by walking from one to the other himself (De Rouvray 2005, p. 83). His methodology was fully

\footnotetext{
${ }^{3}$ On the Laura Spelman Rockefeller Memorial and social science, see Bulmer and Bulmer (1981).

${ }^{4}$ Before the first World War, more than $25 \%$ of economists publishing in the Quarterly Journal of Economics, the Journal of Political Economy, and the American Economic Reviews - were not academics (Stigler 1965, p. 45)
} 
in line with the empirical approach of institutionalist economists at that time: "first-hand observations of living human beings, including their direct interrogation and the use of governmental or privately gathered statistical data obtained from protocols or interrogations of the individuals in question" (Bulmer and Bulmer 1981, p. 348).

After completing his $\mathrm{PhD}$, Willits became the dean of the Wharton School of Business, served in the Hoover administration, and helped create (with the support of the social sciences division) the NBER, which he presided over (1934-1936) and directed (19361939). During his tenure as the head of the division from 1939 to 1955 , Willits continued to support institutional economics even if it was declining in academia. For instance, when Tjalling Koopmans published "Measurement without theory" in 1947, a critique of Arthur Burns and Wesley Mitchell's work at the NBER, the president of the Foundation, Raymond B. Fosdick, took alarm, but Willits persuaded him to continue his support for empirical and basic research (Rutherford 2005, pp. 121-122). Nonetheless, Willits was well aware that significant changes were taking place in economics. In 1951, he represented economics as comprised of two distinct groups:

The first I very profoundly respect. It is composed of men who know economics theoretically, empirically, and through experience, and who know a lot besides economics. . . The second group is very sharply separated from the first; with respect to them my arrogance of opinion runs free. This group includes various categories of today's conventional economists. It is usually composed of men who are not close to what really happens or why it happens but engage in a most adroit game of formal logic or higher mathematics. I cannot develop enthusiasm about these, yet they are in the great majority. I have brought myself to recommend grants for them because I do not feel that Rockefeller Foundation grants should be limited to my narrow prejudices, but I must confess that I find it harder and harder to do so. (quoted in Rutherford 2005, p. 125)

As early as 1944, Willits was eager to support empirical, quantitative and historical approaches in economics. Economics interested the Rockefeller Foundation's social science division because economic stability was regarded as a prerequisite for democracy: it was necessary "to learn how to manage our economic system so as to provide a high measure of employment and production under conditions consistent with the democratic tradition". 5 In its 1944 general report, the Foundation underlined that economic integration was the basis of the

\footnotetext{
${ }^{5}$ Social Sciences by Willits, excerpt from Plans for the future work of the Rockefeller Foundation, Nov. 1944, p. 48; folder “P\&P-Reports PRO 36-38a 1945," RG3 S910 B3 F18 -RFA-RAC.
} 
"development of the modern world." in Europe. Within four years, it more than doubled the funds allocated to projects outside the US—-which represented $28 \%$ of its total budget in 1944 - to more than $60 \%$ in 1947.7

In 1944, it was difficult to form a clear idea of the situation in Europe. ${ }^{8}$ Thus, the first task of the social sciences division was to ascertain Europe's needs. Willits' idea was to send emissaries to visit various institutions and report on the concrete situation in academia and policy circles. From then on, the reports by emissaries were a constant source of ideas and a guide to policy. ${ }^{9}$

As early as February 1944, Rockefeller's officers made contact with former European fellows to determine Europe's needs. For instance, Etienne Dennery, a member of the French National Liberation Committee, was asked about possibilities for postwar actions in France. ${ }^{10}$ In the fall of 1944, Alexander Makinsky, the Rockefeller's officer in charge of Europe during the war, traveled across Europe to determine how the social sciences division's program could be useful. After meeting academics and politicians from thirteen countries, Makinsky wrote a report in which France received most of the attention. ${ }^{11}$

As they visited universities throughout France, Rockefeller's officers realized the complexity of its academic system. They were lost in "the confusions of Institutes, Ecoles, Centres and other designations that seem to abound here both independent and adjoined to the

\footnotetext{
${ }^{6}$ Rockefeller Foundation Annual report-1944, p. 10, RFA-RAC.

7 In 1944, 2,600,000\$ were dedicated by the Rockefeller Foundation to projects abroad; four years later, 6,985,000\$ were. Rockefeller Foundation Annual report-1944, p. 5; RFA-RAC. Rockefeller Foundation Annual report-1947, p. 6; RFA-RAC.

${ }^{8}$ The Social Sciences in 1944 Analysis of Program by Joseph E. Willits, 20 Oct. 1943; folder "P\&P-Reports PRO 31-35 1942-1943," RG3 S910 B3 F17-RFA-RAC.

9 "I propose that we aid some of the best critical minds to visit various institutions and report on the work, the thinking, the experiments, the policies, the organization and the personnel in different institutions. . . Reports by persons of such critical intelligence would help us to obtain what we need. Their reports would be of value as a source of ideas and as a guide to policy." The Social Sciences in 1944, Analysis of Program by Joseph E. Willits, p. 4, 20 Oct. 1943; folder "P\&P-Reports PRO 31-35 1942-1943, RG3 S910 B3 F17” - RFA-RAC.

${ }^{10}$ Interview with Etienne Dennery, 10 Feb. 1944, John Marshall report, John Marshall Diaries, RFA-RAC.

${ }^{11}$ The French represented almost half of the 228 people interviewed: 105 from France, 59 from the UK, 15 from Poland, 7 from Belgium, 7 from Czechoslovakia, 7 from Holland, 5 from Yugoslavia, 3 from Hungary, 2 from Denmark, 2 from Greece, 2 from Norway, 1 from Austria, and 1 from Luxembourg. Makinsky Report; RG2 S1945 B562 F3829 - RFA-RAC.
} 
University. . . A Apparently the French practice is no more consistent than ours, but it does seem to me they outdo us in numbers."12 Created to support professional training, the academic institutions were divided into two branches: the facultés and the grandes écoles. The former were a disciplinary-based extension of high school. As they focused on training, their research activities were average at best. The facultés de Lettres were responsible for training primary and secondary school teachers, whereas the facultés de droit trained the administrative elite and jurists (Musselin, 2007, p. 712). On the other hand, grandes écoles such as the Ecole Polytechnique, the Ecole des Mines or later, the Ecole d'application de l'INSEE trained engineers.

The French academic system had two shortcomings. First, as they were thought as useless for professional training, the social sciences could not find their place within that system (see Clark 1973). Second, the French academic system was not equipped to conduct advanced research, which explains why the government created appendage institutions, such as the Ecole Pratique des Hautes Etudes (EPHE) and the Centre national de la recherche scientifique (CNRS), which were based on the full-time system (Clark, 1973, p. 11). In addition, a few semi-governmental research centers were created, such as the ISRES and the Institut de Sciences Economiques Appliquées (ISEA). Closely linked to the University, they focused on applied research because they were funded by the government or the private sector.

Rockefeller's officers were aware of the difficult situation of French academia, notably the status of the social sciences. The French government concentrated its resources on economic reconstruction and neglected academia in the decade following the liberation (Pestre 2010, pp. 17-19). Although little information is available on the research funding for the immediate postwar era, historians have managed to evaluate the situation from the late 1950s. For the year 1957, Morrisson $(1975$, p. 1023) calculated that law and letters faculties devoted only 1 to $2 \%$ of their budget to research, and $25 \%$ of research funds were dedicated to the social sciences in the CNRS (Lanfant 1960, p. 21). Trystram (1962, p. 76) estimated that only $5 \%$ of the national research budget was devoted to the social sciences in the early 1960 s. Robert T. Crane, a RF officer, wrote: "The desperate need of the French universities after two wars in which France has been economically drained, is manifest. The case for aid in some form is to my mind clear. French contributions to the intellectual progress of mankind should

\footnotetext{
${ }^{12}$ Buchanan diaries, 22-29 May, 1947, RFA-RAC.
} 
make the weakened condition of these universities of concern to the entire world. ... It appears to me that aside from the factor of morale, aid here would place the social sciences, and especially, economics on a vastly more satisfactory basis in France, and would complement the effort to encourage the development of empirical research."13

\section{EXPLORING FRENCH ECONOMICS}

The architecture of French higher education shaped the identities of French postwar economists by dividing economists into two groups: economists from law faculties and economists trained in engineering schools (Schmidt 2005). Furthermore, the variety of institutions encouraged the development of rival schools of thought. French postwar economics was fragmented, and the French government played an important role in defining the identities of economists (Fourcade 2009).

In the postwar era, the economic role of the State increased considerably both as a banker and an industrialist (Rosanvallon 1993, p. 243), creating a demand for economic expertise. From then on, the government made every effort to increase the amount of economics taken by students trained for the administrative elite. That was the case at the newly created École nationale d'administration (ENA) (see Kolopp 2013) and at the Institut d'études politiques (IEP-Paris), where economics represented roughly one-third of the courses (Dreyfus 2011, p. 128). The establishment of the Institut national de la statistique et des études économiques (INSEE) — the centralized administration mainly devoted to the production of economic statistics - led to the creation of a corps d'état - the administrative elite of statistician-economists (Desrosières 1994). To do so, the government decided to complement the traditional engineering training of the grandes ecoles with a two-year training course on economics and statistics at the newly established Ecole d'Application de l'INSEE, which was created by reforming the Vichy-created Ecole d'Application de la SNS (Nord 2012, p. 151). The training focused on technical knowledge and included courses provided by the Institut Statistique de l'Université de Paris. Students could learn "the creation and the use

\footnotetext{
${ }^{13}$ Robert T. Crane to John H. Willits, 4 Sept. 1947; folder “Crane, Robert T (Visit) 1946-1948," RG 1.1 S 700S B23 F169 - RFA-RAC.
} 
of quantitative material and the concrete analysis of collective phenomena" (Insee 1996, p. 71).

At the same time, the engineers trained in the Grandes Ecoles were hired by public industrial companies. These engineers approached the concrete economic problems of the industries with their substantial training in theoretical and applied mathematics. The leading engineering and mathematical economists devoted most of their time to administration; examples include René Roy (at Ministry of Public Works), Maurice Allais (as director of the Bureau of Mines, Documentation and Statistics, until April 1948), and Pierre Massé and Marcel Boiteux (at Electricité de France). They applied the lessons of their training to economic problems and learned economics on the job by taking a practical approach (for instance Massé at Electricité de France, see Yon 2020). To complement their professional activities, they continued to write academic economics papers to such an extent that today we refer to them as the French marginalists or econometricians (Drèze 1964, pp. 2-8).

Their formal education and on-the-job training were supplemented by two seminars that shaped the development of mathematical economics in France: the theoretical seminar of Roy and the practical seminar of Allais. The audience for the two seminars was composed of public industry managers, such as Massé and Boiteux; and mathematical and statistical students from the Ecole d'Application de l'INSEE and from the Institut de Statistique de l'Université de Paris (ISUP), such as Edmond Malinvaud and Gérard Debreu. However, they rarely had contact with the members of faculties and their occasional exchanges took place outside the formal confines of the discipline. Indeed, since the interwar period, the econometric seminar had interested professors in the faculty of sciences rather than economists in the faculty of law. More significantly, the seminars were designated by the CNRS as applied mathematics rather than economics (Bungener and Joël, 1989, pp. 17-29). Debreu pointed out that the distance between the approach of engineer economists and the methodology defended by economists in law faculties was "immense, perhaps irreducible" (quoted in Düppe 2012, p. 422).

Like economists in law faculties, the director of the social sciences division, Willits was skeptical about the mathematical approach in economics: "I suppose my views stem from a very great aversion to the kind of economist whose work represents an escapism from reality and who builds a great superstructure of mathematical statistics or logical theory, without including a lot of the basic considerations that are to me of the essence of economic 
behavior." 14 After meeting Allais, the leading mathematical economist of the time, he lamented: "He may be as limited in his preoccupation with a mathematical method to the exclusion of any other as are the faculties of Law from their point of view. I remember A. Marshall's dictum: 'In approaching a question of economic policy, take those things that are measurable first, they will constitute somewhat less than half the total'."15

At the time of this judgment, Willits had been in France for a few weeks, trying to understand the important features of French economics. In the winter of 1946, he met representatives of each economics school of thought, some of whom he was not enthusiastic about, such as Maurice Allais, and the liberal and inspecteur des finances Jacques Rueff, who defended a social order (1945) based on the free market (Willits, as already observed, favored the institutionalists, who suggested as a remedy for the inevitable failures of the market an evolutionist institutional arrangement rather than the price mechanism). ${ }^{16}$ Being out of step with mathematical or liberal economists, the director of the division turned his focus on law faculties where economics was taught.

In these disciplinary-based institutions, economics was in a straitjacket: economics courses represented only one course in five, and only 22\% - fifty-nine — of the 269 law faculty professors were economists in 1945 (Marco 2009). French economists complained about this situation. For instance, Jean-Marcel Jeanneney explained to Willits that the quality of economics instruction in the faculties of law was "good for lawyers, but not so good for economists." ${ }^{\prime 17}$ Rockefeller officers and Willits noted the weaknesses of economics in the French higher education system and pointed out the inadequacy of economics teaching and the supervision of lawyers over the discipline. ${ }^{18}$

Furthermore, Rockefeller officers and Willits appreciated the empirical approach of law faculty economists, whereas Robert Marjolin explained to them that in French economics "certain habits of mind that are inimical to empirical work have been established, [and]

\footnotetext{
${ }^{14}$ Letter of Willits to Norman Buchanan, 21 Feb. 1949; folder "500S Institute of economic research, Paris 19471952," RG 1.1 B22 F226, RFA-RAC.

${ }^{15}$ Interview with Allais, 21 Oct. 1946; Willits Diaries, RFA-RAC.

${ }^{16}$ The inspection des finances was the second most prestigious grand corps. The top positions in the Ministry of Finance are almost exclusively reserved for them. On Rueff's specific vision of liberalism, see Daou (2019)

${ }^{17}$ Interview with Jeanneney, 16 Oct. 1946, Willits Diaries, RFA-RAC.

${ }^{18}$ Report to the Rockefeller foundation Robert T. Crane visit to France, Oct. 1946-April 1947; folder "Crane, Robert T Report 1946-1947," RG 1.1 S 700S B23 F170 - RFA-RAC.
} 
general theoretical discussion is preferred to an inductive looking into facts." ${ }^{19}$ Indeed, economics was different in law faculties than in the Grandes Ecoles. The dominant faction in the faculties defended an empirical approach and a rapprochement with the other social sciences to guide economic policy. They called themselves "realistic" economists. ${ }^{20}$ The term "realistic economics" was geared towards rival schools of thought—mathematical and liberal economics - whose assumptions were considered too remote from reality.

Taking an empirical approach, realistic economists hoped to strengthen economic expertise so as to participate in the French economic reconstruction. For instance, Charles Morazé (1947, p. 81) ironically commented on an equation from the engineer economist Michel Cépède: "What! if I could have understood the logistical law and the equation $p t=E p$ $(t)-4 p^{2}(t)$, I would have solved the problem of world hunger?". Similarly, Fourastié (1949, p. 56) considered knowledge based on unrealistic assumptions to be "totally useless in practice." This opinion was shared by other realistic economists such as Jean Lhomme (1950, p. 59) and André Marchal (1953, p. 189). It implied parting with abstraction and unrealistic assumptions because neither "attempt[s] to describe the relationships or developments of concrete phenomena" (Fourastié 1949, pp. 56-57). To realistic economists, abstract knowledge could not provide guidelines for action.

Considering institutional change as a lever for economic policy, realists adopted an empirical approach to study institutions and their transformation. In so doing, they extended the scope of the economic discipline to subjects traditionally considered to be outside the proper realm of the economist (Arena 2000, p. 981). For instance, André Marchal (1950, p. 10) advocated the study of "economic actions and reactions [to be contextualized] in the real and living environment, analyzing the role of institutions, discoveries, major movements of thought, psychological and political training." A year later, in the American Economic Review, his brother Jean Marchal (1951, pp. 549-550) used the metaphor of the human body to justify opening economic analysis to other fields of study, explaining that an organ cannot be fully studied without considering its interactions with others.

\footnotetext{
${ }^{19}$ Interview with Marjolin, 11 Oct. 1946; Willits Diaries, RFA-RAC.

${ }^{20}$ In law faculties, realistic economics represented the mainstream between 1945 and 1970. Its representatives chaired half of the committees granting full professorship. On the agrégation - the national competitive examsee Facchini (2015).
} 
As a result, interactions between economists and other social scientists had to be reinforced. André Marchal (1953, p. 188) hoped that "the interpenetration of the different branches of economics with the other social sciences will lead to new developments". Thus, realistic economists were willing to introduce methodologies inspired by other social sciences into economics. ${ }^{21}$

The orientations of the French realists resembled those of the American institutionalists. Indeed, very much like American institutionalism (Rutherford 2011, p. 9), realistic economics "did not consist of a well-defined 'school' of economics, but as a movement held together by some fairly general methodological, theoretical, and ideological commitments." Furthermore, French realists shared most of the institutionalists' five assumptions as described by Rutherford (2011, p. 347): the "importance of institutions and institutional change", the "emphasis on the role of institutions"; the "view of correct scientific method in social science as empirical and investigational", the "rejection of the highly abstract and overly speculative nature of much orthodox theory", and "greater government regulation of the market and other interventions." The similar methodological orientations of the French realists and the American institutionalists help understand why the Rockefeller Foundation was so interested in economists from the law faculties. They regarded realistic economics as the most appropriate kind with which to bring about the economic recovery of France.

However, Willits and his officers also noticed the weakness of research both in the faculties and by engineering economists. The latter focused mainly on their tasks in the nationalized industries, while the few economic research centers limited the scope of the former. Indeed, in faculties, research was produced by senior professors independently and on their own. In 1945, by Rockefeller's standards, there were only two research centers in economics, that is, centers comprised of economists fully involved in and assisted by a staff: the Institut scientifique de recherches économiques et sociales (ISRES) headed by the economist Charles Rist and the Institut des sciences économiques appliquées (ISEA) of François Perroux. Both received grants from the foundation (see below).

\footnotetext{
${ }^{21}$ A convincing illustration of this proposal is the study of the post-war French inflation by Pierre Bauchet (1952), a Rockefeller fellow: after challenging traditional explanations, he used a sociological approach to show that inflation is determined by the size of the middle class.
} 
In just a few short months, the social science division was able to grasp the main features and difficulties of French postwar economics. Its conclusion was that the traditional higher education system was the main obstacle to strengthening economic research and teaching. After deciding that realistic economics offered the best approach when it came to promoting economic recovery of France, Willits and his officers attempted to enhance its institutional basis and to encourage new standards for economic research. They also sought solutions impart economic knowledge to policy makers. Practically, none of that could be done without navigating between politics and academia.

\section{THE ROCKEFELLER FOUNDATION AND FRENCH ACADEMIA: WALKING}

\section{THE TIGHTROPE}

Willits considered France as a battleground of the conflict between Communism and liberal democracy (Stapleton 2003, p. 108). Visiting France in 1946, he explained his plan: "I stated that I was here to find out what Frenchmen want to do in research, what Frenchmen think will best serve France, and who Frenchmen think should be supported and how. I made clear that I came with no 'line' on my mind." 22 This self-presentation was more in line with the foundation's concerns about being regarded as an imperial organization striving to reorient economic research toward US interests. The foundations did not want to be perceived as a US organization because Makinsky reported during his trip that "the popularity of Americans throughout the Continent, but particularly in France, is unfortunately at its lowest ebb." ${ }^{23}$ In fact, Willits maintained the social science division agenda, which attempted to enhance economics knowledge by defending the empirical and institutionalist approach, promoting full-time researchers and creating modern research centers. Although its political agenda was marked by opposition to communism, the Rockefeller Foundation meant to influence economic policy by redefining research standards and training in economics in France while maintaining a non-partisan image. As the 1945 report of the Foundation pointed out: "In the social sciences, the Foundation is not an operating body. It cannot create or administer policies. With its funds it supports attempts to clarify issues through research, to train experts and administrators and to facilitate in various ways the administration of policies already

\footnotetext{
${ }^{22}$ Interview with Marjolin, 11 Oct. 1946; Willits Diaries, RFA-RAC.

${ }^{23}$ Makinsky Report, p. 19; RG2 S1945 B562 F3829 - RFA-RAC.
} 
adopted." ${ }^{24}$ Yet, for an institution that supported research institutes providing policy advice, the line between research and advocacy could blur.

Despite its choice to appear non-partisan, the Foundation made every effort to ensure that its action would not be hampered by the political agenda of the French government. It was particularly concerned about the influence of the communists, who participated in the French government until May 1947 and were one of the main political parties of the period. ${ }^{25}$ Communist members of the government were in charge of educational policy in the early post-war, which worried the Foundation. ${ }^{26}$

The first action of the Foundation was to award individual grants to promising fellows. These individual fellowships aimed to support talented junior people while sending them spend time in US research centers. Rockefeller officers gathered information about French researchers from the hosting research centers. From then on, the fellowships were distributed without methodological consideration and were meant to strengthen the skills of people already trained as economists: twelve French economists under thirty-five were granted individual fellowships between 1947 and 1955 (Tournès 2013, p. 306). The grants were directed toward both academic and practicing economists. On their return to higher education or government economic administration, they were supposed to be able to use and teach the new skills acquired abroad. Most of them were young "economists" like Morazé (fellow in 1947), Gérard Debreu (fellow in 1949), Edmond Malinvaud (fellow in 1950), and Maurice Lévy-Leboyer (fellow in 1952), but others were high-ranking civil servants from economic administration. For instance, one civil servant was René Montjoie (fellow in 1953) when he was deputy-director of the Steel Department of the Ministry of Industry and Trade; another was Jacques Lesourne (fellow in 1954), who was Head of the Economic Department at Charbonnages de France, a public institution created to implement the nationalization of the mining corporations at the liberation.

\footnotetext{
${ }^{24}$ Rockefeller Foundation Annual report-1945, p. 186, RFA-RAC.

25 The French Communist Party (PCF) was one of strongest political parties at the liberation: he won the legislative election of 1946 and a third of the deputies were communist.

${ }^{26}$ The communists Henri Wallon and Frederic Joliot-Curie were respectively the First Secretary of the Ministry of Education and Director of the CNRS. "I do not know what your judgment is concerning my suggestion that Janet take as one of the subjects in which she might give some attention in her weekly report the program and policies proposed by the Communist Party in France", Willits to Robert T. Crane, 3 Dec. 1946; folder "Crane, Robert Treat (Visit) 1946-1948," RG1.1 700S B23 F169 - RFA-RAC.
} 
The individual fellowships for promising economists were a first step in the effort to restructure French economics. However, they had limited scope and on their own could not meet the ambitious aims of the foundation which considered that research and training was a long-term task and that real change would only come through institutional transformations. Thenceforth, they focused on research centers to enhance research standards with full-time researchers and collaborative projects. At that time, the only two French research centers using these standards to produce knowledge for framing economic policy were the Institut des sciences économiques appliquées (ISEA) and the Institut scientifique de recherches économiques et sociales (ISRES).

Created in 1931 with the help of a large grant from the Rockefeller Foundation, ISRES was meant "to advance the use of scientific methods in the study of economic and social phenomena (prices, wages, crises, etc.) by subjecting these phenomena to scientific observation and elaboration" (Tournès 2006, p. 51). During the interwar period, the institute produced statistics and economic information that were published in its home journalL'activité économique. The Institute greatly reduced its activity and the publication of its journal during the Second World War, yet still accumulated significant debts, leading its director Charles Rist to contact the social sciences division for assistance as early as $1944 .{ }^{27}$ Between 1945 and 1950, the Foundation provided significant grants for a total amount of $\$ 165,000$ although the Rockefeller officers were not very enthusiastic about the postwar activities of the institute: the first grant was to pay off the debts; the next grants were to provide interim support pending the retirement of Rist. ${ }^{28}$ In the eyes of the Rockefeller officers, Rist — being over seventy and having retired almost fifteen years ago — was not capable of reviving French economics. However, the Foundation continued to support the center mainly because there were only two economics research centers in France and further developments were expected after Rist's retirement. In May 1946, Rist met Willits and

\footnotetext{
27 "During the occupation a skeleton staff has continued some of the Institute's work. To a large extent this work has been supported from Prof. Rist's personal funds. He and his colleague M. Le Maitre have received no salary since 1939. The Institute is in debt to the extent of 181,000 Fr. frs. for rent and taxes." Grant in aid document, 26 April 1945; folder "500S Institute of economic research, Paris 1942, 1944-45," RG1.1 B22 F224 - RFA-RAC. 28 "In view of the forthcoming retirement of Professor Rist, the officers in the Social Sciences are not yet certain whether Rist's Institute or some other organization emerging from the war will be recommended for substantial Foundation support. However, the large part played by the Foundation in initiating the Institute and the competence and prestige of Professor Rist lead to the proposal of this interim grant." Grant in aid document, 18 Jan. 1946; RG1.1 B22 F224 - RFA-RAC.
} 
proposed to launch a research program on international exchange and commerce under the supervision of Henri Bunle, the former director of the Statistique Générale de la France. Their proposal was to produce statistical data on the foreign trade of France and its colonies, describe from the data how foreign trade was conducted, and make international comparisons. ${ }^{29}$ This economic information, published in the quarterly review Chronologie économique internationale, was regarded as relevant: "In the world in which we live, governmental policy as well as the economic decisions of private individuals need to be guided and clarified by numerous well-documented economic publications" explained Marjolin, a trustee of the Institute. ${ }^{30}$ Furthermore, in addition to the production of economic information on foreign trade, the purpose of the center was to train teachers and research workers by completing the education of the best young graduates of French universities. A large grant of $\$ 130,000$ was provided by the Foundation in January 1947. But six months later, the officers were disappointed by the work at the institute, prompting the social sciences division to support the merger of the center into the Sixth Section of the Ecole pratique des hautes études (EPHE). ${ }^{31}$

The ISEA, with François Perroux - a former fellow of the foundation - at its head, looked more promising in the early postwar era. Perroux had created the ISEA in January 1944 with the support of the Banque de France (the French central bank), the Caisse des dépôts et consignations (a public bank devoted to social investment, such as public housing), and the Ecole Libre des Sciences Politiques (a private university devoted to elite training and that became the Institut d'études politiques at the Liberation) (Cohen 2006, p. 581). Since its creation, it had produced empirical knowledge and provided economic expertise for economic planning. Before the liberation, the institute's economists had studied Anglo-Saxon monetary plans (those of Keynes in England, Harry Dexter White in the United States, and James Lorimer Ilsley in Canada). In 1945, when the United Nations experts required that each country implement a system of national accounts, the Commissariat general au plan-the administrative institution in charge to implement French economic planning-turned to

\footnotetext{
${ }^{29}$ Research project - Album of International Exchange and French Foreign Trade, 29 July 1946; folder "500S Institute of economic research Paris 1946," RG1.1 B22 F225 - RFA-RAC.

${ }^{30}$ Marjolin to Willits, 22 Oct. 1946; folder "500S Institute of economic research Paris 1946," RG1.1 B22 F225 - RFA-RAC.

31 "My impression of the Institute was far from favourable. . . I did have the feeling that there was not a great deal going on." Buchanan diaries, 5 June 1947; folder "500S Institute of economic research Paris 1947-1952," RG1.1 B22 F226 - RFA-RAC.
} 
Perroux's Institute to create a French national accounting system. The result was a mimeograph, published a year later, which emulated Anglo-Saxon economic accounting methods and "can be considered as the first French essay on national accounts" (Terray 2002, pp. 32, 35). From then on, “one of the ISEA's essential activities [was] to publish studies and reports commissioned by the administration" (Etner and Silvant 2017, p. 423). The ISEA's work was fully in line with the Rockefeller's objective of advising policymakers while conducting pure academic research, meaning not politically biased. It was "regarded [by the Foundation] as the most promising center of economics" and accordingly received strong support. ${ }^{32}$ In August 1946, the Rockefeller offered a grant to Perroux and his assistant, Pierre Pujade, to visit American economists. This grant was the first installment of many: between 1946 and 1966, the Foundation provided the ISEA with more than $\$ 100,000$ so that it was able to produce economic expertise for the French economic planning administration.

Both centers achieved the first aims of the Foundation by producing expertise for policymakers, implementing full-time research and completing the training of economists. However, the Rockefeller Foundation (R.F.) was aware of the large need in France for men able to formulate economic policy. ${ }^{33}$ This need could not be achieved by either institute owing to their limited scope. ${ }^{34}$ For the Foundation, the economics discipline could be further developed by improving the training provided to economists. That training could strengthen and promote the empirical approach among academic economists, those in public administration and in the private sector. Thus, Willits wondered "whether the R.F. could do anything to help nearer the source, namely in influencing the training in universities," but the idea was dismissed very quickly for two reasons. ${ }^{35}$ First, French economists advised against it. Marjolin insisted: "No, the universities must do that themselves, as a result of criticisms

\footnotetext{
${ }^{32}$ Inter-office correspondence, JH Willits, 15 Jan. 1951; folder “500 ISEA (1951-1952),” RG1.2 S500 B17 F153 - RFA-RAC.

33 "Such Frenchmen give the highest priority to increasing the supply of young social scientists trained in the realistic analysis of social issues. The problems left by the war, the political-economic tasks of government, the demands of universities, and the need of men able to guide and inform public opinion all emphasize that this need comes first." Grant in aid document, 16 Jan. 1947; folder "500S Institute of economic research, Paris 1942 , 1944-45”, RG1.1 B22 F224 - RFA-RAC.

34 "The research institutes should produce a small number of very good students. Candidates for the doctorate in the Univ[ersity] of Paris should be encouraged to write their theses in research institutes. The institute should be free from the university" Interview with Jeanneney, 16 Oct. 1946; Willits Diaries, RFA-RAC.

${ }^{35}$ Interview with Marjolin, 11 Oct. 1946; Willits Diaries, RFA-RAC.
} 
passed back to them from people who are at the institutes or beyond." ${ }^{36}$ Second, Willits himself worried about political obstacles created by the faculties' hiring process. In October 1946, he was invited by Jacques Rueff at the agrégation and remarked: "It is a far cry from the freedom of choice in English and American institutions to this system. If a truly political minister came in, one wonders what would happen to University freedom." ${ }^{37}$ Indeed, the faculties were not free to select their own economics professors who were recruited by means of the agrégation - a national competitive examination. After passing the examination, the candidates chose which universities to go to according to their ranking. A grant to universities to improve economists' training seemed useless. The Foundation had to find another solution, which they did after meeting with Morazé.

Morazé was a go-between for academia and the political world. He was close to the government, thanks to his participation in the Resistance. His professor's chair and membership on the editorial board of the historical journal Annales gave him academic legitimacy. ${ }^{38}$ At the liberation, Morazé focused on the reform of higher education, particularly in social sciences. ${ }^{39}$ Furthermore, he was involved in the reform of Sciences-Po and was a member of the French delegation at the UNESCO founding conference (Morazé 2007). During that conference in 1946, he met John Marshall from the RF, who has been promptly "more than ever impressed by Morazé." ${ }^{40}$ Marshall explained to him that the Rockefeller Foundation was a little disappointed by the Rist Institute and Sciences Po, and that it aspired to do more elsewhere (Morazé 2007, p. 171).

In association with Pierre Auger, the French director of higher education, Morazé proposed to create a new section- the sixth—at the Ecole Pratique des Hautes Etudes

\footnotetext{
${ }^{36}$ Interview with Marjolin, 11 Oct. 1946; Willits Diaries, RFA-RAC.

${ }^{37}$ Interview with Rueff, 14 Oct. 1946; Willits Diaries, RFA-RAC.

38 The journal was founded in 1929 by Marc Bloch and Lucien Febvre "in order to promote a new kind of history, and it continues to encourage innovation. The leading ideas behind Annales might be summarized briefly as follows. In the first place, the substitution of a problem-oriented analytical history for a traditional narrative of events. In the second place, the history of the whole range of human activities in the place of a mainly political history. In the third place - in order to achieve the first two aims - a collaboration with other disciplines: with geography, sociology, psychology, economics, linguistics, social anthropology, and so on.” (Burke 1990, 1-2)

${ }^{39}$ Morazé claimed the legacy of the historian Marc Bloch's to reform French education system. He did so by publish his article "The French education crisis," in which he recalled the positions of the Annales' founder on the shortcomings of French education (Morazé 1945).

${ }^{40}$ Interview with Morazé and Fawtier, 5 May 1947; John Marshall Diairies, RFA-RAC.
} 
(EPHE). In March 1947, Auger explained that the new section could resolve "the familiar difficulties of having economics in the law faculty. ... He stressed repeatedly that such a new 'sixth section' as proposed would be the means whereby people really trained in economics, i.e. possessing doctor degrees, could be produced. [Auger] believes that this is the only practicable means of ever getting economics and social science in general out from under the law faculties' domination." 41

The Sixth Section had many advantages over the law faculties. First, it made it possible to teach all social sciences including economics, whereas economics was taught in the law faculties and the other social sciences in the literature faculties. Furthermore, it liberated economic training from the domination of lawyers. The idea was not to make the Sixth Section an academic research center exclusively or to reproduce the training required to become academic. Instead, the aim was to produce useful knowledge for businessmen and politicians by taking the opposite approach to what was being taught in law faculties at the time. This was explained by Lucien Febvre - the future president of the institution - in a letter supporting the Sixth Section: "The instruction they [faculties] dispense, with an eye to professional examinations, to the young people under their charge, is dogmatic and didactic instruction, having to do essentially with doctrines and not at all with the methodological, practical and technical instruction which should be given the young workers so needed in economic and social activities." ${ }^{42}$ In the funding request sent to the Rockefeller Foundation, Auger noted that the final purpose of the section was to dispense a theoretical and practical training for social scientists to provide teaching and to provide technical and research staff for the universities and faculties of law, the government, private institutions, and the National Center for Scientific Research (CNRS). ${ }^{43}$

To improve training in economics, the Sixth Section had another advantage: its mode of recruitment. At the Ecole Pratique des Hautes Etudes (EPHE), it was different from that of the faculties and it allowed the hiring of people without academic qualification: each section

\footnotetext{
${ }^{41}$ Interview with Pierre Auger, 27 March 1947, folder "500R EPHE," RG1.2 S500 B16 F146, RFA-RAC.

${ }^{42}$ Febvre to the Rockefeller Foundation, 18 Nov. 1947; folder "500R EPHE," RG1.2 S500 B16 F146 - RFARAC.

43 "The final purpose of the section is the theoretical and practical formation of social scientists. It would provide teaching, technical and research staff for the Universities and Faculties of Law, the Governmental and private institutions, the National Center for Scientific Research (CNRS)." Pierre Auger to Rockefeller Foundation, 5 Nov. 1947; folder “500R EPHE,” RG1.2 S500 B16 F146 - RFA-RAC.
} 
of the EPHE was free to recruit as it pleased. For instance, persons who had not earned a doctorate could still be appointed to the EPHE, by a vote of all the professors in the Section. This meant that the Section enjoyed a less constraining environment for teacher recruitment which in turn better conformed to the expectations of the Foundation. Indeed, the founders of the Sixth Section were able to recruit individuals with practical knowledge regardless of their academic credentials. This freedom of recruitment would help the Section create a new curriculum to train practicing economists.

The comparative advantage of the Section over the law faculties made the Foundation especially confident, and Auger himself had great hope for the new establishment, which would represent a "real improvement in the status of the social sciences in France." 44 In December 1947, the Foundation provided a \$30,000 grant for the creation of the new Section and Auger hoped that despite its limited scope at the time, the proposal would be further developed in the future, his "plan [being] to abolish ultimately other sections and turn the Ecole wholly into the social fields." 45

In the first few years following the creation of the section, economics was given pride of place among the social sciences. Half of the Section's funds were earmarked for economics, which represented no less than one-third of the courses. But the newly appointed economists - all coming from the law faculties - focused on gaining more academic legitimacy and set aside the diffusion of their research to administration and business circles. Accordingly, economists focused on publishing. The newly created research center for economics in the Sixth Section, the Centre d'études économiques (CEE), published twelve master's theses, and edited three courses taught by Jean Fourastié and one by Charles Bettelheim. Likewise, the Sixth Section's economists founded the Revue économique. Although this strengthened realistic economics, the diffusion of economic research seemed forgotten.

As we have seen, the aim of the Foundation was not merely to develop academic knowledge but also to disseminate it to public officials and the private sector. The Sixth Section's economists neglected the dissemination of their knowledge, which displeased the

\footnotetext{
${ }^{44}$ Pierre Auger to Rockefeller Foundation, 5 Nov. 1947; folder "500R EPHE," RG1.2 S500 B16 F146 - RFARAC.

${ }^{45}$ Robert T Crane to JH Willits, 4 Sept. 1947; folder “Crane, Robert T (Visit) 1946-1948," RG 1.1 S 700S B23 F169 - RFA-RAC.
} 
members of the French government and Rockefeller officers alike. At the head of the Section, disagreement was perceptible as well. In 1951, Febvre wrote to the director of higher education: "I'll be by your side to do something new. To increase the efficiency of a machine [Sixth Section] perhaps a little too expensive and a little too detached from the current contingencies to provide France, in particular with these executives of practicing economists, whom I thought from the very first minute, because the law faculties provide us with economists from the chair, and that is fine, but we must train economists of action, and it is to those that I thought above all: France needs it". 46 A first response was to launch a partnership with the Association professionnelle des banques in 1953, leading to the creation of four courses given by former bankers (Benest 2019, pp. 123-128). The main effort to redress the situation came from the Rockefeller Foundation.

In the early 1950s, new economic research centers were created and the Rockefeller Foundation's policy evolved under the guidance of Frederik C. Lane, who was appointed representative of the social sciences division in Paris from 1951 to 1954. Considering "the mess French economics [was] in", he attempted to capitalize on the early results of the Foundation's work by seeking to coordinate the activities of French research centers. ${ }^{47}$ For him, "the way to get cooperation between the various French institutes is to give each small funds. ${ }^{48}$ In fact, the amount of the grants remained as they had been for economists who defended the empirical approach promoted by Willits; it was the nonempirical economists, such as Allais, who received small grants. In Allais's case, he received around $\$ 5000$ to hire two assistants.

At first glance, the grant to François Divisia's econometrics center at the Ecole Polytechnique might be surprising because it would seem to legitimize the mathematical approach, of which Willits did not approve. In fact, "Divisia did public economic accounting and was the supporter of concrete facts" (Georges Morlat quoted in Bungener and Joël, 1989, p. 29). Even if Divisia's center was relatively small (he had only two assistants and a dozen students), it had collaborated with economic government administration since its creation in 1950: "The task of the laboratory is to provide 'basic research' for the needs of administrative

\footnotetext{
${ }^{46}$ Febvre to the general director of higher education, 30 May 1951; Fonds secrétariat direction EHESS (Braudel), 20180531/2, Archives nationales.

${ }^{47}$ Willits, 27 June 1951; folder “401 LSE,” RG2 (1951) B536 F3586 - RFA-RAC.

${ }^{48}$ FC Lanes to JH Willits, 25 June 1953; folder "Paris-Ecole Polytechnique 1954-1957," RG 1.2 S500 B16 F144 - RFA-RAC.
} 
or business practitioners." ${ }^{49}$ Its main task was to prepare an inter-industrial study, in partnership with the Service d'études économiques et financière of the Ministry of Finance, and it reviewed economic analyses produced by the Secretariat for Economic Affairs. Furthermore, one of the two assistants, Pierre Maillet, was involved with planning economic administration. In complement, Divisia fostered collaboration among the French economic research centers such as the Rist and Perroux institutes, a collaboration that, unlike solo projects, allowed research findings to be brought together and synthesized. ${ }^{50}$ Finally, the economics professor at the Ecole Polytechnique had "an important and influential position in the training of economists" as perceived the Rockefeller Foundation. ${ }^{51}$ Indeed, he provided a "high scientific education, designed for practical applications" to the students who were eventually hired by the high government administration and public industries after their training. ${ }^{52}$ He refused to teach theoretical economics and preferred instead empirical knowledge; thus, the syllabus of his courses contained a part dedicated to descriptive economics. Clearly, the activities of the Divisia research centers were in line with Rockefeller's expectations and the foundation granted it \$55,000 from 1950 to 1956.

The main goal of the Foundation - to gather and coordinate French economics research-led it to focus on centers that it already supported. Disappointed with the initial activities of the Sixth Section, the Rockefeller encouraged the merging of the Centre d'études économiques (CEE) at the Sixth Section and the former Rist's institute which had been transformed into the Service d'études de l'activité économique de la structure sociale (SEAE). In 1952, Lane received separate funding requests from the two centers. Jean Meynaud, the new director of the CEE, applied for a grant to promote new research topics "by looking into some of the important public administration departments such as Reconstruction or the Planning Office [.... affirming] the Center's desire to maintain close contact between

\footnotetext{
${ }^{49}$ Report for the academic year 1953-1954, p. 18, undated; folder "Paris-Ecole Polytechnique 1954-1957," RG 1.2 S500 B16 F145 - RFA-RAC.

${ }^{50}$ Grant submission of François Divisia to FC Lanes, undated; folder "Paris-Ecole Polytechnique 1954-1957," RG 1.2 S500 B16 F144 - RFA-RAC.

${ }^{51}$ Excerpt from Minutes DSS staff Meeting \#160, 22 July 1953, folder "Paris-Ecole Polytechnique 1954-1957," RG 1.2 S500 B16 F144 - RFA-RAC.

${ }^{52}$ Retrospective table of the three school years 1950-53 and future prospects, undated; folder "Paris-Ecole Polytechnique 1954-1957,” RG 1.2 S500 B16 F144 - RFA-RAC.
} 
theoreticians and practitioners in the economic field." ${ }^{, 53}$ And Jean-Marcel Jeanneney, the newly appointed director of the SEAE, wished to pursue the former agenda of the Institute by studying economic business cycles and publishing its results in its home journal—L'activité économique (Dreyfus 2011, p. 131). These two requests provided Lane with opportunity of merging the two centers in the hope that "this new collaboration could some day become the French 'National Bureau of Economic Research'." ${ }^{54}$ Within these two research centers, realistic economists represented the lion's share, which suited Lane's "desire to avoid pure theory and pure mathematics and to make more studies of economic facts in their social context." ${ }^{, 55}$ Likewise, the administrative complementarity of the two centers was an asset. The CEE was a public research center while the SEAE was a private institute. Consequently, the CEE could get public research funding while the SEAE could and did get private funding by providing expertise. In late December 1952, Meynaud sent a grant request for a common research program to Lane, who forwarded it to the head of the SSD by underlining that "the aim is to give economic theorists a better understanding of the actual conditions in which various schemes of economic analysis may be applied and to supply a more factual frame of reference for the formulation of economic policies." 56

In February 1953, the Rockefeller Foundation provided a $\$ 60,000$ grant to the common research program that $\mathrm{CEE}$ and SEAE would undertake together. For its part, the CEE produced analyses for the government administration on monetary issues, which was an important matter at the time due to high inflation. The SEAE, in contrast, focused on building up databases for a large study of the French economy, while at the same time providing studies on industry. The research teams from each center began to collaborate. Everything seemed to be going well, but after one year of work the collaboration collapsed: the election of Perroux at the Sixth Section led to the resignation of nine of the CEE's eleven economists and eventually Rockefeller's funding was suspended.

\footnotetext{
${ }^{53}$ J. Meynaud to F.C. Lane, 3 July 1952; folder "FNSP French Economy 1952-1953," RG 1.2 S500 B18 F161 RFA-RAC.

${ }^{54}$ Granted file, 26 Feb. 1953; folder "FNSP French Economy 1952-1953," RG 1.2 S500 B18 F161 - RFARAC.

${ }^{55}$ FC Lane to JH Willits, 1 Aug. 1952; folder "FNSP French Economy 1952-1953," RG 1.2 S500 B18 F161 RFA-RAC.

${ }^{56}$ Lane to Willits, 28 Dec. 1952; folder "FNSP French Economy 1952-1953," RG 1.2 S500 B18 F161 - RFARAC.
} 
The attempt to renew the Centre d'études économiques (CEE) by the appointment of Georges-Théodule Guilbaud as its new head failed. An applied mathematician, Guilbaud focused on game theory and had been one of the most important defenders of the Recherche Opérationnelle (OR) since the 1950s. ${ }^{57}$ Although his research was applied and OR was fully in line with the initial project of the Sixth Section, the shift toward Area studies in its scientific agenda meant that economic research would not be revived at the CEE. For instance, in 1956 - only one year after being appointed as the head of the CEE - Guilbaud created its Bureau Universitaire de la Recherche Opérationnelle outside the Section under the institutional umbrella of the Institut Statistique de l'Université de Paris. Considering that the European recovery was under way, the Rockefeller Foundation reoriented its programs toward non-Western cultures and phased out its programs in Europe in the mid-1950s (Stapleton 2003, pp. 112-3): no more fellowships and economics programs received funding, with the exception of the ISEA, but the grant was to an economics research project in Africa, where ISEA had offices.

\section{CONCLUSION}

During the decade after World War II, the division of the Social Sciences of the Rockefeller Foundation devoted more than $\$ 400,000$ (more than $\$ 4,000,000$ in today's dollars) to strengthen French economics. ${ }^{58}$ Willits and his officers supported an empirical methodology and full-time research by funding economics research centers which conducted collaborative research at a time when French economists usually worked on their own. The funding was meant to improve economic analysis, the results of which were to be shared with government officials and private sector businessmen. Once disseminated, this knowledge was to stabilize the post-war political context still marked by the influence of the communists in France.

The Rockefeller Foundation did not fully reshape economic training and research in France. The main reason for that was its fear of interfering with the government's activities limited the scope of its action in France, making the impact of the foundation less pronounced than it had hoped. Nevertheless, the Rockefeller's grants gave academic French economists

\footnotetext{
${ }^{57}$ On Guilbaud, see Barbut (2008); on French Recherche Opérationnelle, see Drevon (1969) and Roy (2006); and on the economics-cybernetics nexus in France, see Assaf and Duarte (2020, pp. 867-872) and Le Roux (2018, pp. 451-509)

${ }^{58}$ Considering the inflation rate, calculate from the dollar value in 1950 and in 2020.
} 
the means to conduct their research outside faculties and to escape the domination of lawyers, at a time when most economic research was conducted within law faculties. At the same time, by supporting realistic economics, the Foundation helped maintain a dialogue between economics and other social sciences.

Finally, it is not true that French economists were isolated from the rest of the world. Nevertheless, the encounter between French economists and the American foundation did not change the identity of French academic economists: French economists continued to focus on local economic matters and they took a decidedly empirical approach, while US economists were increasingly favoring a more theoretical approach. Although often perceived as a national characteristic, the sociological school in the French economic discipline was partly perpetuated thanks to the external support of the Rockefeller Foundation at the end of the Second World War.

\section{REFERENCES}

Allais, M. 1953. "Le Comportement de l'Homme Rationnel Devant Le Risque: Critique des Postulats et Axiomes de l'Ecole Américaine." Econometrica 21 (4): 503-546.

Arena, Richard. 2000. "Les économistes français en 1950." Revue économique 51 (5): 9691007.

Assaf, Matheus, and Pedro Garcia Duarte. 2020. "Utility Matters: Edmond Malinvaud and Growth Theory in the 1950s and 1960s." History of Political Economy 52 (5): 863894.

Barbut, Marc. 2008. "G.-Th. Guilbaud." Mathématiques \& Sciences Humaines 183 (3): 5-7.

Bauchet, Pierre. 1952. "Evolution Des Salaires Réels et Structure Économique." Revue Économique 3 (3): 297-337.

Benest, Serge. 2019. "Recomposition de l'ordre disciplinaire et analyse des faits économiques : le cas de la VIe Section et de l'Ecole des Hautes Etudes en Sciences Sociales." Phd Dissertation. Cachan: ENS Paris-Saclay.

Bourguignon, François, and Roger Guesnerie. 1996. "L'Economie : un redéploiement." In Jacques Revel and Nathan Wachtel, ed., Une école pour les sciences sociales: de la VIe section à l'École des Hautes Études en Sciences Sociales. Paris, France: Les Éditions du Cerf, pp. 325-337.

Bulmer, Martin, and Joan Bulmer. 1981. "Philanthropy and Social Science in the 1920s: Beardsley Ruml and the Laura Spelman Rockefeller Memorial, 1922-29.” Minerva 19 (3): 347-407.

Bungener, Martine, and Marie-Eve Joël. 1989. “L'essor de l'économétrie Au CNRS." Cahiers Pour l'histoire Du CNRS 4: 1-33.

Burke, Peter. 1990. The French Historical Revolution: The Annales School, 1929-89. Stanford, California: Stanford University Press. 
Clark, Terry Nichols. 1973. Prophets and Patrons: The French University and the Emergence of the Social Sciences. Cambridge, Massachusetts: Harvard University Press.

Cohen, Antonin. 2006. "Du corporatisme au keynésianisme." Revue française de science politique 56 (4): 555-592.

Daou, Marie. 2019. "Jacques Rueff and the Liberal Social Order: A Liberal Interventionist." Journal of the History of Economic Thought 41 (4): 573-591.

De Rouvray, Cristel Anne. 2005. "Economists Writing History: American and French Experience in the Mid 20th Century." Phd Dissertation. London, UK: The London School of Economics and Political Science.

Desrosières, Alain. 1994. "Une Particularité Française: L'économiste-Statisticien.” Courrier Des Statistiques 70: 49-54.

Drevon, J. 1969. "Sur l'état de la recherche opérationnelle en France." Revue française d'informatique et de recherche opérationnelle. Série verte 3 (V2): 3-11.

Dreyfus, Emmanuel. 2011. "L'enseignement de l'économie à Sciences Po de 1945 à 1989 Idées économique et formation des élites." Phd Dissertation. Paris, France: Ecole doctorale d'histoire moderne et contemporaine.

Drèze, Jacques H. 1964. "Some Postwar Contributions of French Economists to Theory and Public Policy: With Special Emphasis on Problems of Resource Allocation." The American Economic Review 54 (4). American Economic Association: 2-64.

Düppe, Till. 2012. "Gerard Debreu's Secrecy: His Life in Order and Silence." History of Political Economy 44 (3). Duke University Press: 413-449.

Etner, François, and Claire Silvant. 2017. Histoire de la pensée économique en France: depuis 1789. Paris, France: Economica.

Fourastié, Jean. 1949. "Les nouveaux courants de la pensée économique." Annales. Économies, Sociétés, Civilisations 4 (1): 52-64.

Fourcade, Marion. 2009. Economists and Societies: Discipline and Profession in the United States, Britain, and France, 1890s to 1990s. Princeton, New Jersey: Princeton University Press.

Gemelli, Giuliana. 1995. Fernand Braudel. Paris, France: Odile Jacob.

Insee. 1996. Cinquante Ans d'INSEE... Ou La Conquete Du Chiffre. Paris, France: INSEE.

Jeanpierre, Laurent. 2004. "Des hommes entre plusieurs mondes: étude sur une situation d'exil." Phd Dissertation. Paris, France: École des hautes études en sciences sociales.

Kolopp, Sarah. 2013. "De la modernisation à la raison économique.” Genèses 93 (4): 53-75.

Lanfant, Marie L. 1960. "The Sociological Sciences in France: Organization and Development Since 1945." Political Research, Organization and Design 3 (8). SAGE Publications: 19-28.

Le Merrer, Pascal. 2012. "L'affirmation de l'économie comme discipline scientifique : une histoire française particulière.” Tracés n HS-11 (3): 163-174.

Le Roux, Ronan. 2018. Une histoire de la cybernétique en France (1948-1975). Paris, France: Classiques Garnier.

Lhomme, Jean. 1950. "Les phénomènes économiques en tant que phénomènes «nombreux ». Essai sur la notion d'aberrance économique." Revue économique 1 (1): 45-59.

Loyer, Emmanuelle. 2005. Paris à New York: Intellectuels et artistes français en exil. Paris, France: Grasset and Fasquelle.

Marchal, André. 1950. "Economistes et historiens." Revue économique 1 (1): 5-36. doi:10.3406/reco.1950.406731.

Marchal, André. 1953. La pensée économique en France depuis 1945. Paris, France: Presses Universitaires de France - PUF.

Marchal, Jean. 1951. "The Construction of a New Theory of Profit." The American Economic Review 41 (4): 549-565. 
Marco, Luc. 2009. "Le Cocotier Des Économistes Français: Documents de GRH 19311964." Management \& Sciences Sociales, no. 6: 287-317.

Mazon, Brigitte. 1985. "Fondations américaines et sciences sociales en France 1920-1960: de la genèse de la VIe section de l'Ecole pratique des hautes études à la fondation de la Maison des sciences de l'homme." Phd Dissertation. Paris, France: École des hautes études en sciences sociales.

Mazon, Brigitte. 1988. Aux origines de l'École des hautes études en sciences sociales: Le rôle du mécénat américain, 1920-1960. Paris, France: Les Éditions du Cerf.

Morazé, Charles. 1945. "La Crise de l'éducation Française." Annales d'histoire Sociale 8 (2): $120-126$.

Morazé, Charles. 1947. "Économie et Réalité.” Annales. Économies, Sociétés, Civilisations 2 (1): 80-86.

Morazé, Charles. 2007. Un historien engagé: mémoires. Paris, France: Fayard.

Morgan, Mary S, and Malcolm Rutherford. 1998. From Interwar Pluralism to Postwar Neoclassicism. Durham, N.C: Duke University Press.

Morrisson, Christian. 1975. "Les Moyens Des Sciences Sociales En France." Revue Économique 26 (6): 1004-1023.

Musselin, Christine. 2007. "France." In James J. F. Forest and Philip G. Altbach, ed., International Handbook of Higher Education. Dordrecht, Netherlands: Springer Netherlands. pp. 711-728.

Nord, Philip. 2012. France's New Deal: From the Thirties to the Postwar Era. Princeton, New Jersey: Princeton University Press.

Pestre, Dominique. 2010. "Dix thèses sur les sciences, la recherche scientifique et le monde social, 1945-2010." Le Mouvement Social n 233 (4): 13-29.

Popa, Ioana. 2015. "Aires culturelles et recompositions (inter)disciplinaires." Actes de la recherche en sciences sociales 5 (210): 60-81.

Popa, Ioana. 2016. "International Construction of Area Studies in France during the Cold War: Insights from the École Pratique Des Hautes Études 6th Section." History of the Human Sciences 29 (4-5): 125-150.

Popa, Ioana. 2017. "Diplomaties culturelles occidentales en conjoncture de détente. Le lancement d'un programme d'échanges académiques Est-Ouest à la 6e Section de l'EPHE." Relations internationales, no. 169 (June): 69-86.

Rosanvallon, Pierre. 1993. L'Etat en France : de 1789 à nos jours. Paris, France: Seuil.

Roy, Bernard. 2006. "Regard historique sur la place de la recherche opérationnelle et de l'aide à la décision en France." Mathématiques et sciences humaines. Mathematics and social sciences, no. 175 (December): 25-40.

Rueff, Jacques. 1945. L'Ordre social. Paris: Recueil Sirey.

Rutherford, Malcolm. 2005. "Who's Afraid of Arthur Burns?' The NBER and the Foundations." Journal of the History of Economic Thought 27 (2): 109-139.

Rutherford, Malcolm. 2011. The Institutionalist Movement in American Economics, 19181947: Science and Social Control. Cambridge, UK: Cambridge University Press.

Schmidt, Christian. 2005. "Economics in France." In A. W. (Bob) Coats, ed., The Development of Economics in Western Europe Since 1945. Londres, UK: Routledge, pp. $125-142$

Scot, Marie. 2011. La London School of Economics and Political Science, 1895-2010: Internationalisation Universitaire et Circulation Des Savoirs. Paris, France: Presses universitaires de France.

Seim, David. 2007. "'Perhaps We Can Hit upon Some Medium of Course': Rockefeller Philanthropy, Economic Research, and the Structure of Social Science--1911-1946." Phd Dissertation. Iowa: Iowa State University. 
Stapleton, Darwin H. 2003. "Joseph Willits and the Rockefeller's European Programme in the Social Sciences." Minerva 41 (2): 101-114.

Stigler, George J. 1965. "Statistical Studies in the History of Economic Thought." In Essays in the History of Economics, 31-50. Chicago, Ill and London, UK: The University of Chicago Press.

Terray, Aude. 2002. Des francs-tireurs aux experts: organisation de la prévision économique au Ministère des finances, 1948-1968. Paris, France: Comité pour l'histoire économique et financière de la France.

Tournès, Ludovic. 2006. "L'Institut Scientifique de Recherches Économiques et Sociales et Les Débuts de l'expertise Économique En France (1933-1940).” Genèses 65 (4): 49_ 70.

Tournès, Ludovic. 2008. "La fondation Rockefeller et la construction d'une politique des sciences sociales en France (1918-1940)." Annales. Histoire, Sciences Sociales 63e année (6): 1371-1402.

Tournès, Ludovic. 2013. Sciences de l'homme et politique: Les fondations philanthropiques américaines en France au XXe siècle. Etudes. Paris, France: Garnier.

Trystram, J.P. 1962. "The Organization of Social Science Research in France.” Social Science Information 1 (3): 74-92.

Yon, Guillaume. 2020. "Building a National Machine: The Pricing of Electricity in Postwar France.” History of Political Economy 52 (S1): 245-269. 